\title{
Research about the Influence of Incentive Method towards Executive and Corporation Performance Based on Multiple Regression Model
}

\author{
NanhaoWang, Yichong Tang, Fan Liang
}

\author{
School of Information Science and Technology, \\ Sun Yat-sen University (SYSU), Guangzhou, 510006, China \\ leonard_wangsysu@outlook.com
}

\begin{abstract}
With the advent of economic globalization, the corporation plays a vital role in the development of economy. Contemporary society is confronted with a common difficulty that how to manage corporations effectively, and how to maximize corporation revenue. According to the Principal Agent Theory, the division of ownership and management right makes it limited to develop corporations. This paper intends to explore how to improve the corporation performance by providing executives with proper incentive system, based on the Incentive Theory. Furthermore, we use statistical software SPSS to validate the relationship between incentive method toward executive and corporation performance based on multiple regression model, and hope that the result of this paper could bring realistic meanings to contemporary enterprises.
\end{abstract}

Keywords: Multiple Regression, Principal Agent Theory, Incentive Theory, SPSS

\section{Introduction}

Stockholding system is a common structure among large company nowadays. Stockholders are owners of company, while senior executives are decision makers and administrators, whose operation directly affect company performance and prospect, as well as benefit of stockholders. However, increase of senior executive's income sometime contradict to long-term profit of company, as well as that of stockholders. So an appropriate incentive method towards them seem to be considerably important to healthy development of company.

Selecting and implementing effective incentive method is always a difficult task in human resource field. Because human's demand can be classified in several levels, which is raised by Maslow, while senior executives usually desire something other thansalary after their basic need is satisfied. So a valid incentive method should put that into consideration. In this paper, we will propose a theory of multivariate regression analysis to think about the effect of various incentive methods on senior executive and company performance.

Currently, most state-of-the-art incentive theories are based on general staff, and those research working on senior executive merely concerned their salary, which lack diversity and comprehensiveness of analyze on incentive method. We address basic salary, shareholding ratio of senior executives, and company recognition from society in our proposed method, and it is apparently more convictive. 
As increasing private enterprises show up and develop in China, we hope to take reference on successful companies overseas, bring appropriate manage patterns back to native enterprises, and motivate the most of their potential.

\section{Background}

\subsection{Data selection}

In this paper, we mainly consider CEO (Chief Executive Officer), CFO (Chief Financial Officer), and those whose salary and shareholding ratio is mentioned in annual reports as our research targets. There are two reasons of this choice: (1) These people are decision makers but not the owners of company; (2) The data of their salary and shareholding ratio can be obtained directly from Proxy Statement on the website of SEC (Securities and Exchange Commission).

Usually, the salaries of senior executives are made up of base salary, bonus, stock award and particular award differ from each company. For the unity of data in comparison, we use base salary as their specific emolument.We also use company reputation score published by Reputation Institute as index of each company's reputation, because Reputation Institute conducts global survey and evaluates each large company in seven aspects, including product/services, innovation, workplace, governance, citizenship, leadership and financial performance, which ensure the authority of its results.Moreover, we consider earnings per share as the indicator to company performance, for it can represent the operating result of one company during a particular period objectively.

\section{2 relevant theory}

Principal agent theory mainly concerns about the agency relationship between stockholders and senior executives who are hired by board of directors according to the ideas of those stockholders. Jensen and Meckling[1] believed that the separation of ownership and control power result in the behavior that senior executives give up the benefit of stockholders and chase their own profit, which generates agency cost. Because those senior executives are usually not the possessors of companies, they may acquire only a small proportion of earnings after they undertake all responsibility and do their best to operate the companies, especially when they take companies' long-term interests into consideration. Murphy and Jensen[2] put forward that the key to the improvement of relation between principal and agent is the reduction of agency cost. Based on the principal agent theory, principal must provide appropriate incentive or benefit to agent such as senior executives, and make thorough as well as specific contract in order to lower agency cost. As a result, agents will maximize interests of principal and insure their own profit at the same time.

Maslow's hierarchy of needs [5] present that humans are all in need, while the desire to meet their need is also the motivation and stimulation to their work. These need can be classified into several levels, sorted as physiological, safety, belongingness and love, esteem, self-actualization, and self-transcendence. After basic level is satisfied, humans will start to chase stronger sense of achievement to meet higher level need, which may include incentive and reputation mentioned in our research. 


\section{Modeling}

Based on the research framework in this paper, we take earnings per share (EPS) as dependent variable, salaries of of senior executives, shareholding ratio and company reputation as independent variables. Therefore, a multiple regression model about the influence of incentive method towards executive on corporation performance is built and shown as follows:

$B=\alpha_{1}+\alpha_{2} \cdot$ salary $+\alpha_{3} \cdot$ share $+\alpha_{4} \cdot$ reputation

where $B$, salary, share, reputationdenote EPS, basic salary of senior executives and company reputation.

\section{Experiments}

\section{1 data collection}

The object of this research is the American public company. In this paper, three IT companies-Apple, Google and Intel-are chosen as the objects. The reason is that competition among IT companies becomes more serious nowadays. Once there emerge sometroubles and problems about the management of a company, it would be easy for this company to quit the market. Therefore, there exists a relatively strong relationship between incentive methods towards senior executives and corporation performance.

In this paper, we collect relevant data of these three companies through American Securities and Exchange Commission (SEC). SEC is authoritative and publishes all required reports such as annual reports of public corporations every year. After persistent research, we succeed in finding what we want from corresponding reports.

(1) In financial statements and supplementary data of 10-K (see Fig. 1), we could find the total number of restricted stock units of a company each year (which denotes $\mathrm{Tr}$ ).

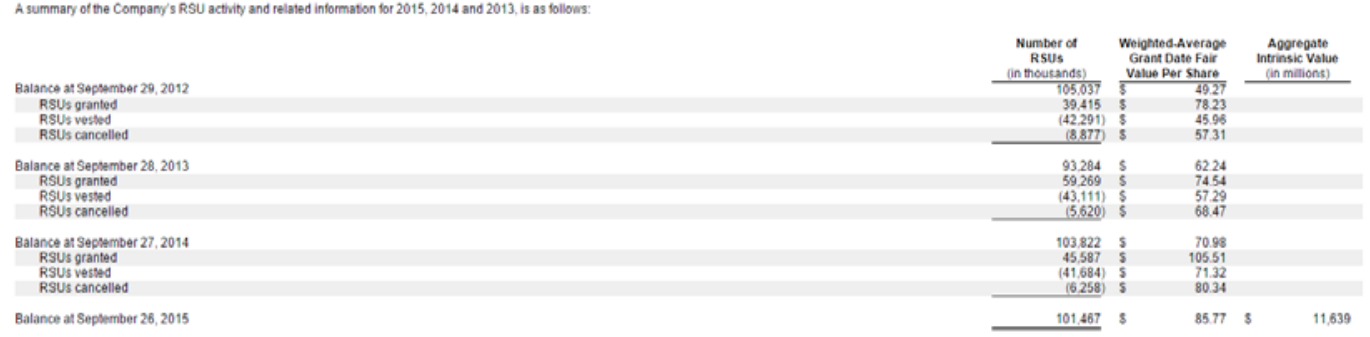

Fig. 1

(2) In security ownership of certain beneficial owners and management of Proxy Statement (see Fig. 2), we could find shares of common stock owned by senior executives (which denotes $\mathrm{C}$ ) and the total number of corporation common stock (which denotes Tc). 
SECURITY OWNERSHIP OF CERTAIN BENEFICIAL OWNERS AND MANAGEMENT

The following table shows certain information as of January 5, 2015 (the "Table Date"), unless otherwise indicated, with respect to the beneficial ownership of the Company's common stock by (1) each person

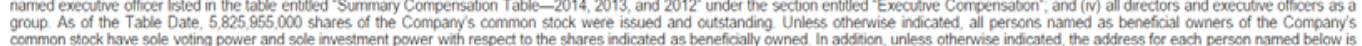
common stock have sole voting power and sole investment

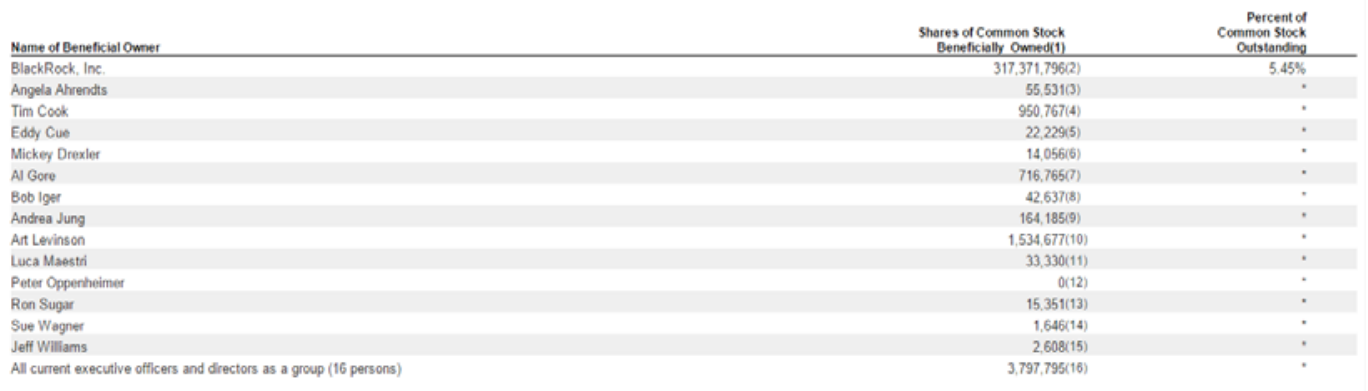

Fig. 2

(3) In outstanding equity awards of Proxy Statement (see Fig. 3), we could find the number of restricted stock owned by senior executives (which denotes R).

Outstanding Equity Awards at 2014 Year-End

The following table shows information regarding the outstanding equity awards (consisting of RSU awards) held by each of the named executive officers as of September 27, 2014.

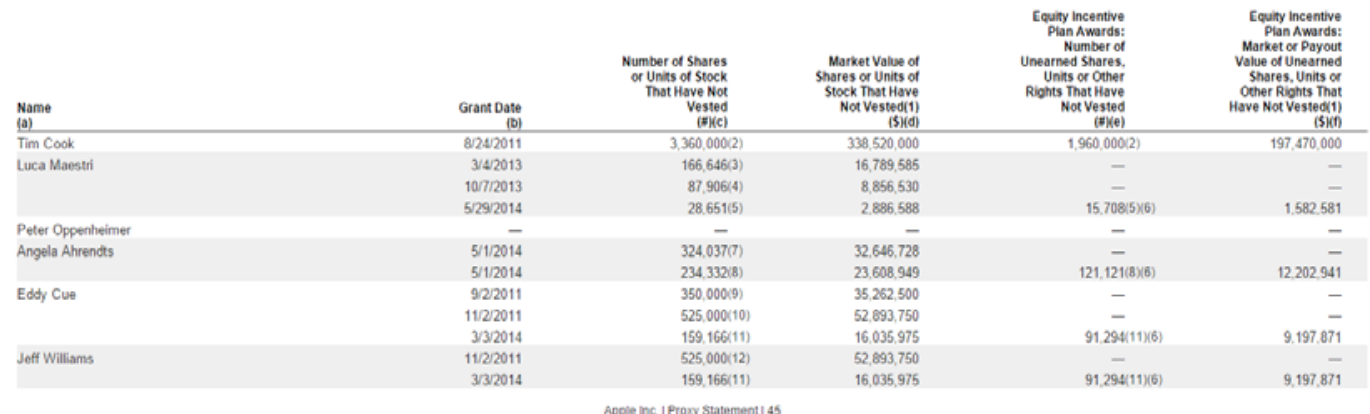

Fig. 3

(4) In executive compensation table of Proxy Statement (see Fig. 4), we could find basic salaries of corporation senior executives (which denotes $\mathrm{S}$ ).

Executive Compensation Tables

Summary Compensation Table-2014, 2013, and 2012

The following table stows information regarding compensation of each named executive officer for 2014, 2013 and 2012, except in the cases of Mr. Maestri and Ms. Alirendts, who were not named executive
officers in 2013 and 2012

\begin{tabular}{|c|c|c|c|c|c|c|c|}
\hline $\begin{array}{l}\text { Name and Principal } \\
\text { position } \\
\text { la) }\end{array}$ & $\begin{array}{c}\text { Year } \\
\text { (b) }\end{array}$ & $\begin{array}{c}\text { Solary } \\
\text { (5Kc) }\end{array}$ & $\begin{array}{l}\text { Bonus } \\
\text { (Sk)(d) }\end{array}$ & 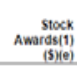 & 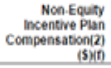 & $\begin{array}{l}\text { Allother } \\
\text { compen } \\
\text { sation } \\
(5)(q) \\
\end{array}$ & $\begin{array}{c}\text { Total } \\
\text { (s)in) }\end{array}$ \\
\hline $\begin{array}{l}\text { Tim Cook } \\
\text { Chief Execulive Officor }\end{array}$ & $\begin{array}{l}2014 \\
2013 \\
2012\end{array}$ & $\begin{array}{l}1.748 .462 \\
1.400 .006 \\
1377718\end{array}$ & $=$ & = & $\begin{array}{l}6,700,000 \\
2800000\end{array}$ & $\begin{array}{l}774,176(3) \\
52.721 \\
1.274\end{array}$ & $\begin{array}{l}9.222630 \\
4252727\end{array}$ \\
\hline 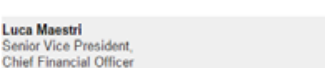 & $\begin{array}{l}2012 \\
2014\end{array}$ & $\begin{array}{l}1.357 .718 \\
717.211\end{array}$ & - & $11,335,043$ & $\begin{array}{l}2.800 .000 \\
1,608,255\end{array}$ & $\begin{array}{c}17.274 \\
3(2,292(4)\end{array}$ & $\begin{array}{r}4,174,992 \\
14,002,001\end{array}$ \\
\hline 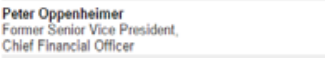 & $\begin{array}{l}2014 \\
2013 \\
2012\end{array}$ & $\begin{array}{l}987.596 \\
8660651 \\
805.400\end{array}$ & $\bar{z}$ & $66,169,750$ & $\begin{array}{l}3.437,500 \\
1.750 .000 \\
1.600 .000\end{array}$ & $\begin{array}{l}132.624(5) \\
16.791 \\
16.412\end{array}$ & $\begin{array}{r}4.517 .720 \\
2.632 .852 \\
68.591 .562\end{array}$ \\
\hline $\begin{array}{l}\text { Angela A Ahrendts } \\
\text { Senior Vice President, Retail and Online Stores }\end{array}$ & 2014 & 411,538 & 500,000 & $70,001,196$ & $1,648,352$ & $790,038(6)$ & $73,351,124$ \\
\hline Eddy Cue Eenior Vice President, Intement Software and Services & $\begin{array}{l}2014 \\
2013 \\
2012\end{array}$ & $\begin{array}{l}947.566 \\
8660.061 \\
805.400\end{array}$ & $\begin{array}{l}\bar{z} \\
\bar{z}\end{array}$ & $20,000,900$ & $\begin{array}{l}3.437,500 \\
1.750 .000 \\
1.600 .000\end{array}$ & $\begin{array}{l}59,743(7) \\
31.044 \\
39.753\end{array}$ & $\begin{array}{l}24,445.739 \\
2647.105 \\
50.420 .415\end{array}$ \\
\hline $\begin{array}{l}\text { Jeff Williams } \\
\text { Senior Vice Prosident, Operations }\end{array}$ & $\begin{array}{l}2014 \\
2013 \\
2012\end{array}$ & $\begin{array}{l}947.596 \\
866.061 \\
805400\end{array}$ & $\bar{z}$ & $20,000,900$ & $\begin{array}{l}3.437,500 \\
1,7500000 \\
1600000\end{array}$ & $\begin{array}{l}17.23989) \\
16,7919\end{array}$ & $\begin{aligned} 24.4032235 \\
22632.855 \\
686512\end{aligned}$ \\
\hline
\end{tabular}

Fig. 4

(5) In earnings per share of $10-K$ (see Fig.5), we could find EPS of each corporation. 


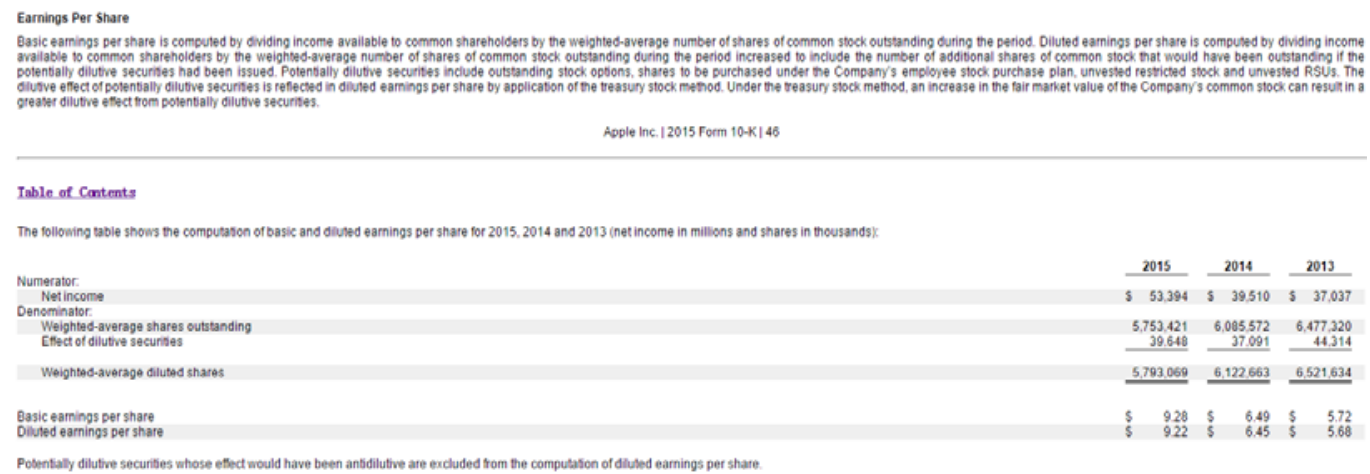

Fig. 5

(6) Moreover, we could find company reputation values (which denotes P) and ratings each year from official website of Reputation Institute.

\subsection{Data processing}

In the process of collecting data, we figure out that senior executives of these three companies change a lot recently, which results in the data loss of some senior executives. Therefore, based on the different situations of each company, we finally take senior executives who are in position from 2012 to 2014 as objects of this study. Besides, some senior executives are not only the founders of their company but also the principal stakeholders. These senior executives are not considered in this research. Specific senior executivelist is shown as follows.

Table 1

\begin{tabular}{|l|l|l|}
\hline Company Name & Senior Executive & Position \\
\hline Apple & Tim Cook & Chief Executive Officer \\
\cline { 2 - 3 } & Peter Maestri & Former Chief Financial Officer \\
\cline { 2 - 3 } & Eddy Cue & $\begin{array}{l}\text { Senior Vice President, } \\
\text { Internet Software and Services }\end{array}$ \\
\cline { 2 - 3 } & Jeff Williams & Senior Vice President,Operations \\
\hline \multirow{5}{*}{ Google } & Eric.E.Schmidt & Executive Chair \\
\cline { 2 - 3 } & Patrick Pichette & $\begin{array}{l}\text { Senior Vice President, } \\
\text { Chief Financial Officer }\end{array}$ \\
\cline { 2 - 3 } & David C.Drummond & $\begin{array}{l}\text { Senior Vice President, } \\
\text { Corporate Development, } \\
\text { Chief Legal Officer, and Secretary }\end{array}$ \\
\cline { 2 - 3 } & OmidKordestani & $\begin{array}{l}\text { Senior Vice President, } \\
\text { Chief Business Officer }\end{array}$ \\
\cline { 2 - 3 } & Bntel & Chief Executive Officer \\
\cline { 2 - 3 } & Renee J.James & President \\
\cline { 2 - 3 } & Andy D.Bryant & Chairman of the Board \\
\cline { 2 - 3 } & Stacy J.Smith & $\begin{array}{l}\text { Executive VIce President, } \\
\text { Chief Financial Officer }\end{array}$ \\
\hline
\end{tabular}

Based on the data above, each variable of this model could be obtained by computational formula shown as follows.

(1) $\mathrm{B}=\mathrm{EPS}$ 
(2) Salary $=\frac{1}{n} \sum S$

(3) Shares $=\left(\frac{1}{T c} \sum_{i=1}^{n} C+\frac{1}{T r} \sum_{i=1}^{n} R\right) X 100 \%$

(4) Reputation $=\mathrm{P}$

Specific data are shown as follows.

Table 2

\begin{tabular}{|r|r|r|r|r|r|}
\hline 4 & \multicolumn{1}{|c|}{ B } & \multicolumn{1}{c|}{ C } & D & \multicolumn{1}{|c|}{ E } \\
\hline 1 & & Salary & Shares ( $)$ & Reputation & EPS \\
\hline 2 & Apple 2012 & 943,480 & 1.56 & 78.49 & 6.38 \\
\hline 3 & 2013 & 999,547 & 1.63 & 74.65 & 5.72 \\
\hline 4 & 2014 & $1,147,813$ & 6.95 & 75.6 & 6.49 \\
\hline 5 & Google2012 & 850,000 & 13.34 & 78.05 & 16.41 \\
\hline 6 & 2013 & 850,000 & 11.05 & 77.15 & 19.41 \\
\hline 7 & 2014 & 850,000 & 8.43 & 77.3 & 21.37 \\
\hline 8 & Intel2012 & 690,000 & 8.90 & 75.42 & 0.5 \\
\hline 9 & 2013 & 768,125 & 1.80 & 74.98 & 0.53 \\
\hline 10 & 2014 & 828,250 & 2.80 & 74.9 & 0.77 \\
\hline
\end{tabular}

\subsection{Result analysis}

In order to further analyze the influence of incentive method towards executive on corporation performance,we build a multiple regression model. The regression result using professional software SPSS is shown as follows.

\begin{tabular}{|l|l|l|l|l|}
\hline Model & $\mathrm{R}$ & R Square & $\begin{array}{l}\text { Adjusted } \\
\text { Square }\end{array}$ & $\begin{array}{l}\text { R Std. Error of } \\
\text { the Estimate }\end{array}$ \\
\hline 1 & $.807^{\mathrm{a}}$ & .651 & .442 & 6.19665 \\
\hline
\end{tabular}

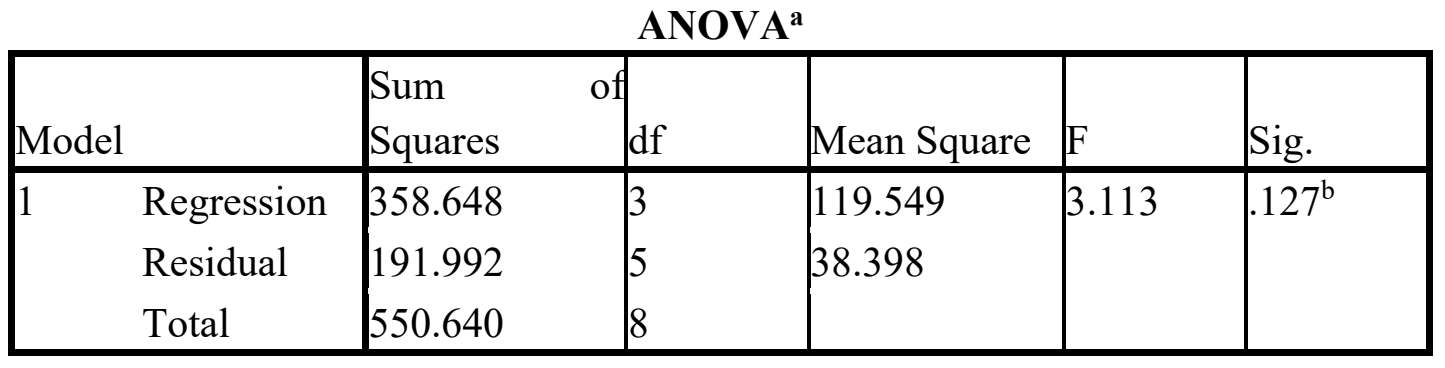

\section{Coefficients $^{\mathrm{a}}$}

\begin{tabular}{|c|c|c|c|c|c|c|}
\hline \multirow{2}{*}{\multicolumn{2}{|c|}{ Model }} & \multicolumn{2}{|c|}{ Unstandardized Coefficients } & \multirow{2}{*}{$\begin{array}{c}\begin{array}{c}\text { Standardized } \\
\text { Coefficients }\end{array} \\
\text { Beta }\end{array}$} & \multirow[b]{2}{*}{$\mathrm{t}$} & \multirow[b]{2}{*}{ Sig. } \\
\hline & & B & Std. Error & & & \\
\hline \multirow[t]{4}{*}{1} & (Constant) & -197.661 & 126.156 & & -1.567 & .178 \\
\hline & VAR00006 & $1.124 \mathrm{E}-5$ & .000 & .182 & .671 & .532 \\
\hline & VAR00007 & .930 & .563 & .502 & 1.651 & .160 \\
\hline & VAR00008 & 2.498 & 1.686 & .442 & 1.481 & .199 \\
\hline
\end{tabular}

From the above regression result, we could notice that $\mathrm{R}^{2}$ is 0.651 , and adjusted $\mathrm{R}^{2}$ is 0.442 , which indicates that the model fits well and that the dependent variable could 
be explained by independent variables. The significance of $\mathrm{F}$ in variance test table is 0.127, which indicates that there exists significant linear relation between the independent variable and dependent variables. The significance of Shares and Reputationin parametric test table is 0.160 and 0.199 respectively, which indicates there exists relatively significant relation between these two independent variables and the dependent variable. The significance of Salary is 0.532 , which indicates that there does not exist significant relation between this independent variable and the dependent variable. We could obtain the linear equation by SPSS as follows.

$\mathrm{B}=\alpha_{1}+\alpha_{2} \cdot$ salary $+\alpha_{3} \cdot$ share $+\alpha_{4} \cdot$ reputaton

Restricted by the difficulty of searching relevant data, only limited data are used in this research to obtain the multiple regression model. Therefore, the next step of our research is to search more relevant data to verify this model.

\section{Conclusion}

Nowadays, stockholding system is very common among financial world. According to principal agent theory, we discover the contradiction between principal's profit and agent's benefit, and try to figure out a solution to that. Many researchers have put forward their theory, but many of them only focused on the relationship between basic salary of senior executive and company performance, which is not convictive. During the period of research, we are inspired by the incentive theory and Maslow's hierarchy of needs, and discovered that the combination of salary, stock share and company reputation can bring better effect of stimulation and incentive on senior executive, and further influence on company performance. Based on these conjectures, we built corresponding linear model, and verified the validity of this model by multiple linear regression analysis.

This model has its own practical significance, since a large amount of potential private enterprise appeared along with economic development in China. Compared to state-owned enterprise, they have more operating freedom to implement incentive mechanism, including share allocation and reputation improvement, and finally achieve better company performance.

\section{Reference:}

[1]Jensen M C, Meckling W H. Theory of the firm: Managerial behavior, agency costs and ownership structure[J]. Social Science Electronic Publishing, 1976, 3(76):305-360.

[2]Jensen M C, Murphy K J. Performance Pay and Top-Manager Incentives[J]. Journal of Political Economy, 1990, 98(2):225-264.

[3]Murphy K J. Corporate performance and managerial remuneration: An empirical analysis[M]// Treatment of cancer and allied diseases /. Hoeber, 1958:11-42.

[4]Mcguire J W, Chiu J S Y, Elbing A O. EXECUTIVE INCOMES, SALES AND PROFITS[J]. American Economic Review, 1966, 52(4):753-761.

[5]Maslow A T, Understand T, Explore A. Maslow's Hierarchy of Needs[J]. 2004, 67(2):172-178. 